ELORE (ISSN 1456-3010), vol. 17 - 1/2010.

Julkaisija: Suomen Kansantietouden Tutkijain Seura ry.

[http://www.elore.fi/arkisto/1_10/saatteeksi_koskinen_1_10.pdf]

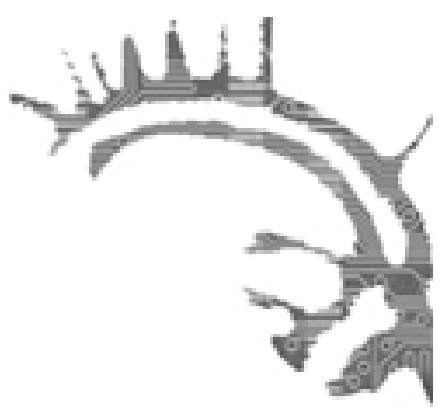

\title{
SAATTEEKsi: Aistien TIETOA MAAIlMASTA
}

\section{Eerika Koskinen-Koivisto}

Ajatus Eloren teemanumerosta aistikokemukset tutkimuskohteena syntyi tutkimusaineistoa läpikäydessä. Huomasin tuon tuostakin olevani haisevan, likaisen ja meluisen tehdastyön keskellä. Vaikken ollut elämässäni astunut hiilikattilan enkä saranasorvin ääreen, kertojani onnistui välittämään omat kokemuksensa niin, että hänelle tuttu ympäristö heräsi eloon myös minun mielessäni. Kirjallisiin aineistoihin sukeltaessa ja kentälle astuessa tulee usein vastaan aisteihin vetoavaa ja niiden kautta välittyvää tietoa. Oman tutkimusprosessini aikana minua on askarruttanut, miten tuo tieto välittyy ja miten se löytää tiensä tutkimuksiin. Miten kulttuurin tutkijat lähestyvät osin fysiologian ja psykologiankin puolelle asettuvaa inhimillistä toimintaa?

Tähän teemanumeroon kirjoittaneet tutkijat eivät suinkaan ole yksin aistitietoon liittyvien kysymystenasettelujensa kanssa. Kulttuuristen tulkintojen tutkijakoulun syysseminaarissa 2008 luennoinut professori Regina Bendix (Georg-August-Universität, Göttingen) innosti perinteentutkijoita aistitiedon pariin: eri kulttuurien ja ryhmien makutottumukset ja tuoksumieltymykset sekä äänimaisemat hiljaisuuksineen ja säröineen tarjoavat ehtymättömän aineiston, johon perehtyä. Aistien maailman tutkiminen vaatii kuitenkin herkistymistä, jota Bendix on kollegoineen pohtinut kuuloaistimuksia ja kuuntelemista tutkineen projektiryhmänsä artikkelikokoelmassa Über das (Zu-)Hören. Herausgegeben von der Projektgruppe Zubören (2003). Teemanumeron tekstit esittelevät keskeistä aisteihin liittyvää tutkimusta sekä yleisesti että yksittäisiin aisteihin keskittyen. Aistitietoa lähestytään eri aikoina ja erilaisissa konteksteissa: muuttuvissa maisemissa, varhaismodernissa uskomusperinteessä, nykyihmisen urbaanissa arjessa sekä tutkijan työssä. Myös professori Dorothy Noeysin (Ohio State University, Columbus) haastattelu valottaa aistitiedon merkitystä etnografisessa kenttätyössä. Noyes kertoo omista intensiivisistä ja varsin ruumiillisista kenttätyökokemuksistaan katalonialaisessa vuotuisjuhlassa (Noyes 2003). 
Artikkelien keskittyessä aisteihin liittyvän tiedon olemukseen, tulkintaan ja käyttöön jää yksi tärkeä näkökulma hieman taka-alalle, nimittäin aistikokemuksista kirjoittamisen ja kirjoitetun tekstin herättämien aistikokemusten pohdinta. Ensimmäisen käden aistihavaintojen ohella myös mielikuvituksen tuotteet kuten elokuvat ja fiktiivinen teksti voivat synnyttää voimakkaitakin aistimuksia. Muistelmat ja matkakertomukset sisältävät usein rikkaita kuvauksia paikasta, äänistä, tuoksuista ja mauista. Mehevät kuvaukset mahdollistavat lukijan eläytymisen tuntemattomaan, matkaamisen toiseen todellisuuteen. Yksi elämäni parhaista lukukokemuksista on ollut Patrick Süskindin elokuvaksikin ehtinyt teos Parfyymi (2000), joka kuvaa poikkeuksellisen lahjakkaan, mutta kieroutuneen mestarihaistajan pakkomielteitä. Luin kirjan osallistuttuani tämän numeron kolumnistin Jan Löfströmin kurssille Aistien historiallista antropologiaa Jyväskylän yliopistossa vuonna 2002. Kaunokirjallisen tekstin analysoiminen ja luova kirjoittaminen toimivat loistavina harjoituksina tutkijan mielikuvitukselle. Viimeisin kirjaseikkailuni, amerikansuomalaisen professorin Stephen Kuusiston (University of Iowa, Iowa City) muistelmateos Planet of the Blind (1998), jossa hän kuvaa elämäänsä sokeana näkevien ehdoilla, voisi hyvin olla kulttuuriantropologian tai folkloristiikan kurssivaatimuksissa. Kirjallisuutta ja runoutta opiskellut, nykyään kirjoittamista (creative nonfiction writing) opettava Kuusisto on aikoinaan vieraillut Helsingin yliopistossa Fulbright-stipendiaattina. Hän kertoo muistelmissaan paitsi kokemuksistaan vieraassa kulttuurissa myös suhteestaan suomalaiseen kansanrunouteen.

Aistien avulla astutaan perinteisiä oppiainerajoja rikkovalle monitieteiselle kentälle kuten Jan Löfström kolumnissaan osoittaa. Normaalista poikkeavat kokemukset maailmasta kiehtovat esimerkiksi neurologi Oliver Sacksia, joka pohtii ihmisyyden olemusta neurologista ongelmista kärsiviä potilaita kuvatessaan teoksissaan Mies, joka luuli vaimoaan hatuksi (2000) ja Antropologi Marsissa (2006). Lääkäri Sacksia voisi luonnehtia humanistiksi, ellei jopa kulttuurin tutkijaksi. Fysiologiaan saati sitten neurotieteisiin viittaavia näkökulmia usein vierastetaan kulttuurintutkimuksessa, vaikka kokemuksellisuus ja ruumiillisuus - molemmat suosittuja näkökulmia nykytutkimuksessa - yhdistävät tiedonintressiltään erilaisia ihmistieteitä. Toisen tieteen kohtaaminen ja polkujen risteäminen voi parhaimmillaan johtaa sellaisiin oivalluksiin, jotka uudistavat koko tieteenalaa kuten edellä mainitun Oliver Sacksin tutkimukset.

Tämän lehden lukijoille lienee itsestään selvää, että kulttuurintutkimuksellinen, erityisesti uskonnon, perinteen, paikallisuuden ja jatkuvuuden huomioiva tutkimus tuottaa tärkeää tietoa aistein havaittavasta maailmasta ja ihmisen tavoista toimia; ovathan aistien välittämästä tiedosta tehdyt tulkinnat ja aistien väliset hierarkiat riippuvaisia vallitsevista kulttuurisista ja historiallisista kehyksistä. Sacksin ja monien muiden tieteidenvälisyyteen uskovien tutkijoiden uraauurtavasta työstä huolimatta luonnontieteillä ja kulttuuritieteillä on varsin vähän yhteisiä tutkimusprojekteja. Ajankohtainen yliopistouudistus yrittää tyrkkiä suomalaista yliopistomaailmaa tällaiseen suuntaan. Vaan löytyyköhän Aalto-yliopiston Otaniemen kampuksella tai Ruskeasuon Medicumissa aikaa tai tahtoa lukaista tämä Eloren numero? Silmälääkäriksi erikoistuva tuttavani oppi uutta luettuaan Stephen Kuusiston muistelmat. New York Times julkaisi hiljattain jutun merkittävää tietoa tuottaneesta poliopotilaiden kokemuksia kartoittaneesta muistitietoprojektista (Johnson 2010). Tärkeän omaa alaa kehittävän, 
syventävän ja kyseenalaistavan perustutkimuksen lisäksi kulttuurintutkijat osaavat ja voivat soveltaa tietoaan. Olkaa hyvä ja lukekaa, mitä kaikkea sanottavaa meillä onkaan maailmasta, jota kukin aistii ja tulkitsee paitsi psyko-fyysisten seikkojen myös kulttuurisen taustansa ja elämänhistoriansa perusteella.

\section{KirJallisuUs}

JOHNSON, KIRK 2010: For Some Survivors, Polio Won't Fade Into the Past [Online]. - New York Times < http://www.nytimes.com/2010/02/03/health/03polio. html $>$ [julkaistu 2.2.2010.]

KUUSISTO, STEPHEN 1998: Planet of the Blind. New York: Delta.

NOYES, DOROTHY 2003: Fire in the Plaça. Catalan Festival Politics After Franco. Philadelphia: University of Pennsylvania Press.

SACKS, OLIVER 2000 (1985): Mies, joka luuli vaimoaan hatuksi. Suom. Marja HelanenAhtola. Helsinki: Tammi.

SACKS, OLIVER 2006 (1995): Antropologi Marsissa: Seitsemän paradoksaalista tarinaa. Suom. Seija Kerttula. Helsinki: Absurdia.

SÜSKIND, PATRICK 2000 (1985): Parfyymi. Suom. Markku Mannila. Helsinki: Otava

ÜBER DAS (ZU-)HÖREN. HERAUSGEGEBEN VON DER PROJEKTGRUPPE ZUHOREN 2003. Beiträge zur volkskunde in niedersachsen 18. Göttingen: Schmerze Verlag.

Filosofian maisteri Eerika Koskinen-Koivisto valmistelee väitöskirjaansa Jyväskylän yliopistossa ja vierailee parhaillaan Yhdysvalloissa Fulbrightstipendiaattina. 